\title{
PERENCANAAN PENETAPAN HARGA
}

\author{
Hanan Fakhira Sa’diyyah \\ Naura Aulia Hafidzah \\ Muhammad Zaidan Mubarak \\ Mumuh Mulyana \\ Sofie Kurnia Asih
}

Selamat berjumpa lagi. Di inisiasi VI akan membahas materi Perencanaan Penetapan Harga. Silahkan pelajari modul 7 dari BMP Perencanaan Pemasaran (EKMA 4569).

Jangan lupa untuk mengerjakan tes formatif modul 7 untuk mengevaluasi kemampuan pemahaman Anda tentang materi tersebut.

Kompetensi Umum $\quad$ : Mahasiswa diharapkan mampu memahami dan menjelaskan konsep dasar dan perancangan perencanaan pemasaran serta aplikasinya dalam bauran pemasaran

Kompetensi Khusus

: Mampu menjelaskan dan Merumuskan Perencanaan

Penetapan Harga

Menjelaskan Pengertian harga

Menjelaskan Penetapan Harga

Menjelaskan Tujuan Penetapan harga

Menjelaskan Pertimbangan dalam penetapan harga

Menjelaskan Metode Penetapan Harga

Menjelaskan Penetapan harga dalam tahapan daur hidup produk

Menjelaskan Adaptasi Harga

\section{Sumber Belajar}

1. Utama

Modul 7 EKMA4569

Perencanaan Pemasaran. Daniel Tumpal. Universitas Terbuka. 2016

2. Tambahan:

- Marketing Management : A Strategic Decision-Making Approach. John W. Mullins and Orville C. Walker, Jr. $7^{\text {th }}$ edition. McGraw-Hill International Edition. 2010

\section{Rangkuman Materi Kuliah}


Harga seperti halnya periklanan, promosi, dan penggunaan tenaga penjualan merupakan bagian dari alat pemasaran. Harga adalah bagian dari alat pemasaran yang lebih mudah dan lebih cepat diubah dibandingkan dengan apabila kita mengubah kampanye periklanan, merombak promosi penjualan, dan mengubah perilaku tenaga penjualan.

Keputusan harga tidak hanya berpengaruh terhadap pendapatan perusahaan tetapi juga berpengaruh terhadap permintaan. Dengan kata lain merubah harga akan berpengaruh terhadap jumlah barang yang dijual. Bertentangan dengan pentingnya kehati-hatian dalam penetapan harga, banyak perusahaan tidak memiliki perencanaan harga. Bahkan sering kali penetapan harga menjadi ajang tarik menarik antara pemasaran dan para akuntan.

Untuk menetapkan kebijakan harga yang masuk akal, perusahaan harus terlebih dahulu memiliki sistem pembiayaan yang akurat yang benar-benar mencerminkan situasi perusahaan. Bila kebijakan perusahaan adalah untuk menghasilkan keuntungan jangka pendek, maka perusahaan harus menerapkan kebijakan harga awal yang tinggi.

Faktor-faktor yang berpengaruh terhadap harga :

1. permintaan;

2. biaya;

3. pesaing;

4. profit perusahaan;

5. sasaran pemasaran;

6. hambatan peraturan.

Tujuan penetapan harga adalah untuk kelangsungan hidup, laba sekarang maksimum, pendapatan sekarang maksimum, pertumbuhan penjualan, skimming pasar maksimum, dan kepemimpinan kualitas produk.

Beberapa pertimbangan dalam menetapkan harga :

1. Permintaan: umumnya semakin rendah harga yang ditawarkan semakin tinggi tingkat permintaan. Hubungan ini tidak berlaku untuk produk-produk yang peka-ego.

2. Biaya: merupakan total biaya tetap (overhead) dan biaya variable yang bervariasi langsung dengan volume produksi.

3. Biaya, Harga, dan Penawaran Pesaing: biaya yang dikeluarkan pesaing harus dipertimbangkan juga untuk mengevaluasi apakah biaya yang Anda keluarkan terlalu tinggi atau terlalu rendah sehingga Anda dapat menerapkan harga yang lebih kompetitif.

Metode penetapan harga :

1. Kurva pengalaman: hubungan antara biaya, harga, dan akumulasi pengalaman. Jika volume produksi (yang berarti pengalaman terakumulasi) dinaikkan, maka biaya total produksi per unit menurun, sehingga harga dapat diturunkan.

2. Penetapan harga dengan cost-plus: dihitung berdasarkan mark-up biaya per unit produk. Metode ini mengesampingkan faktor permintaan.

3. Penetapan harga berorientasi nilai: pelanggan membuat keputusan membeli berdasarkan persepsi nilai, yaitu kesetimbangan antara persepsi kualitas produk terhadap persepsi pengorbanan keuangan. Pelanggan mengevaluasi produk berdasar biaya memperoleh produk, persepsi merek, nilai estetis, dan kegunaan relatif produk. Economic value to the customer adalah harga maksimum yang bersedia dibayarkan pelanggan dibandingkan dengan alternatif terbaik setelah produk Anda. 
4. Penetapan harga lain yaitu penetapan harga nilai, penetapan harga sesuai harga berlaku, dan penawaran harga tertutup.

Daur hidup produk

Daur hidup produk juga akan berpengaruh terhadap penetepan harga produk. Pengaruhnya adalah sebagai berikut:

1. Tahap perkenalan. Dalam tahap ini dapat diterapkan harga rendah yaitu untuk merebut pangsa pasar. Tetapi apabila produk yang diperkenalkan memiliki teknologi yang inovatif dan merupakan terobosan, dapat diterapkan harga yang tinggi (harga skimming), yaitu untuk menunjukkan nilai prestise dari produk.

2. Tahapan pertumbuhan. Dalam tahap ini, terapkan harga rendah yaitu untuk meraih pangsa pasar

3. Tahapan kedewasaan. Dalam tahap ini, terapkan strategi harga yang sama seperti pada tahapan pertumbuhan.

4. Tahapan kejenuhan. Dalam hal ini, stabilkan harga, atau Anda juga dapat mempertimbangkan untuk menaikkan harga.

5. Tahapan kemunduran. Anda dapat mengurangi harga.

Kompetisi yang ada

Pemilihan harga yang Anda kenakan terhadap produk Anda juga dipengaruhi oleh kompetitor Anda. Anda harus menganalisis harga yang dikenakan kompeittor terhadap produk yang mirip dengan produk Anda.

Potensi kompetisi

Harga yang Anda kenakan terhadap produk akan berdampak terhadap kompetitor Anda. Pengaruhnya bisa dalam bentuk menarik kompetitor untuk masuk ke pasar atau sebaliknya menolak kompetitor untuk masuk. Jika Anda dapat menerapkan harga tinggi sehingga Anda dapat emperoleh marjin keuntungan yang besar, maka keadaan ini tidak akan bErtahan lama karena kana memancing kompeitor untuk merapkan hal yang sama.

Posisi produk

Harga yang Anda kenkan terhadap produk harus sejalan dengan profil atau imej yang Anda bangun untuk produk tersebut. Jika produk Anda terdepan dalam teknologi dan merupakan produk terbaik dan terbesar, maka harga yang Anda kenakan harus juga merefleksikan hal tersebut. Jika target pasar Anda adalah pelanggan dengan pendapatan tinggi, maka harga yang Anda kenakan harus memperlihatkan keekslusifan produk. Hal yang sebaliknya juga berlaku untuk produk bagi pasar kelas bawah dimana penerapan harga yang rendah akan menjadi lebih konsisten dengan posisi produk.

Adaptasi harga

Jika bisnis Anda membutuhkan perantara untuk mencapai pelanggan, maka saluran distribusi mengharapkan hadiah untuk layanan yang mereka lakukan. Hadiah ini bisa dalam bentuk besaran marjin untuk produk. Harga yang Anda terapkan begitu keluar pabrik haruslah menguntungkan Anda. Di sisi lain harga masih harus tetap dapat menguntungkan perantara memperoleh marjin yang adil sehingga harga akhir yang dibayarkan pelanggan tidak terlalu tinggi. 
Pemberian diskon

Pengurangan harga atau diskon adalah cara yang paling cepat dalam menaikkan permintaan. Mekanisme ini akan berdampak langsung dan mudah diterapkan.

Keuntungan diferensiasi

Jika produk Anda memiliki kelebihan yang tidak dimiliki produk kompetitor maka Anda dapat menerapkan harga yang lebih tinggi. Dan Anda akan memperoleh pendapatan yang lebih besar.

Perilaku pelanggan

Perilaku konsumen terhadap produk atau layanan Anda atau perilaku terhadap perusahaan Anda karena nama dan reputasi yang telah dibangun juga akan mempegaruhi keputusan harga

\section{Referensi :}

[1] Tumpal, Daniel, 2016. Perencanaan Pemasaran. Universitas Terbuka.

[2] McDonald, Malcolm and Wilson, Hugh. 2011. Marketing Plans: How To Prepare Them, How To Use Them. $7^{\text {th }}$ edition. Wiley.

[3] Mullins, John W. and Walker, Jr. Orville C., 2010. Marketing Management : A Strategic Decision-Making Approach. $7^{\text {th }}$ edition. McGraw-Hill International Edition.

[4] O'Guinn, Thomas C.; Allen, Chris T. and Semenik, Richard J., 2009. Advertising \& Integrated Brand Promotion. $5^{\text {th }}$ Edition. South-Western Cengage Learning.

[5] Crawford, Merle and Benedetto, Anthony Di 2011. New Products Management. 10 Edition. McGraw-Hill International Edition. 2011.

[6] Mulyana, Mumuh. 2019. "STRATEGI PROMOSI DAN KOMUNIKASI." INA-Rxiv. June 12. doi:10.31227/osf.io/v7dfr.

[7] Mulyana, Mumuh. 2019. "MENGANALISIS PERILAKU KONSUMEN.” INA-Rxiv. June 12. doi:10.31227/osf.io/2wj34.

[8] Mulyana, M., 2012. Consumer Behaviour: Sukses Dengan Memahami Konsumen.

[9] Mulyana, M. and Sulistiono, S., 2012. Kewirausahaan: The Long Life Way of Business.

[10] Pauziah, P. and Mulyana, M., 2018. Formulation of The Green Marketing Development Strategy for the Body Shop Botani Square Bogor. In THE INTERNATIONAL CONFERENCE ON ACCOUNTING AND MANAGEMENT SCIENCE (p. 171).

[11] Hidayat, L., Mulyana, M. and Effendy, M., 2018. Membangun Kepuasan Mahasiswa Pengguna Laboratorium Komputer. JAS-PT Jurnal Analisis Sistem Pendidikan Tinggi, 1(2), pp.93-101.

[12] Mulyana, M., PERSEPSI DAN PERILAKU KONSUMEN TERHADAP ONLINE SHOPPING. 